\title{
The Relationship of Hope, Optimism, Self-Esteem, Subjective Well-Being, and Personality in Brazilians and Americans
}

\author{
Claudio S. Hutz ${ }^{1}$, Aida Midgett ${ }^{2}$, Juliana Cerentini Pacico', \\ Micheline R. Bastianello1, Cristian Zanon ${ }^{3}$ \\ ${ }^{1}$ Federal University of Rio Grande do Sul, Porto Alegre, Brazil \\ ${ }^{2}$ Boise State University, Boise, USA \\ ${ }^{3}$ University of San Francisco, São Paulo, Brazil \\ Email: claudio.hutz@gmail.com
}

Received 20 February 2014; revised 22 March 2014; accepted 23 April 2014

Copyright (C) 2014 by authors and Scientific Research Publishing Inc.

This work is licensed under the Creative Commons Attribution International License (CC BY). http://creativecommons.org/licenses/by/4.0/

(c) (i) Open Access

\begin{abstract}
The main objective of this paper was to conduct a cross-cultural study comparing a pool of positive variables in an American and Brazilian sample. The variables were hope, optimism, life satisfaction, affects, self-esteem, and personality. The participants were 179 Americans aged 18 to 61 years and 499 Brazilians aged 17 to 53 years. They answered the following instruments: Adult Dispositional Hope Scale, Life Orientation Test Revised, The Life Satisfaction with Life Scale, Positive and Negative Affect Scale, The Rosenberg's Self-esteem Scale, NEO-PI-R and Bateria Fatorial de Personalidade. The results showed differences between the two samples regarding the correlations between personality and positive psychology variables. Differences in correlations among the positive psychology variables were also found between Brazilians and Americans. The results showed that Americans had higher scores in hope, positive affect and life satisfaction. Brazilians showed higher scores in optimism and negative affect. One possible explanations for these results are cultural differences and social conditions.
\end{abstract}

\section{Keywords}

Positive Psychology, Personality, Cultural Differences

\section{Introduction}

Positive psychology is the scientific study of positive experiences and positive individual traits, and the Institutions

How to cite this paper: Hutz, C. S., et al. (2014). The Relationship of Hope, Optimism, Self-Esteem, Subjective Well-Being, and Personality in Brazilians and Americans. Psychology, 5, 514-522. http://dx.doi.org/10.4236/psych.2014.56061 
that facilitate their development (Duckworth, Steen, \& Seligman, 2005). This is a new area within psychology and appeared at the end of the last century. Although there have been many studies involving hope, optimism, self-esteem and subjective well-being, few measure all these variables simultaneously in cross-cultural studies. To measure them together and in samples from different countries may help to understand better how they interact and how cultural and personality affect them. The aim of this paper is to compare the correlations between positive psychology variables (hope, optimism, self-esteem, life satisfaction and affects) and personality in a sample of Americans and Brazilians.

Hope was defined by Snyder et al. (1991) as the sense of success resulting from the interaction between pathways and agency. There are three components to hope: objective, pathways and agency. The objective is the outcome that the subject seeks to achieve through the pathways when there is enough motivation (agency) to achieve it (Snyder, 2000). Thus, hope is a cognitive process with a motivational component (agency). In the presence of motivation to achieve certain goal, the subject evaluates whether it is achievable and then develops multiple ways to reach it (pathways). The hopeful behavior involves planning and undertaking effective actions that are clearly linked to getting results. For this process to occur in the individual must be motivated from the start for this search. The greater the motivation is, the greater will be the persistence to overcome obstacles.

Peterson and Seligman (2004) pointed out that hope and optimism are forces oriented towards the future. Both refer to future positive expectations. According to Scheier and Carver (1985) optimism involves widespread expectations that good things will happen instead of bad things. During the procedures for the construction of instruments that assess these constructs the authors used self-esteem for convergent validity. Some authors also found positive correlations (from $r=.50$ to $r=.60$ ) between hope, optimism and self-esteem (Wong \& Lim, 2009; Snyder, 2000). Brazilian researchers also found a positive correlation between optimism, hope and between hope and self-esteem (Pacico, Zanon, Bastianello, \& Hutz, 2013).

Self-esteem was defined by Rosenberg (1965) as the assessment made and maintained by individuals about themselves. It indicates an attitude of approval or disapproval about themselves and shows the extent to which individuals believe in themselves, in their ability, and merit. Correlations among hope, optimism and self-esteem were used by Snyder (2000) as evidence of convergent validity for the Adult Dispositional Hope Scale (ADHS). The positive correlation between self-esteem and hope exists because self-esteem increases motivation levels (Aspinwall \& Taylor, 1992) and persistence (Di Paula \& Campbell, 2002). The better the evaluation that subjects make of themselves, the more they believe they can achieve the goals they desire. This is because they also believe that they deserve to achieve them because they have higher levels of self-esteem. The persistence increases because the subjects with high self-esteem scores believe in their ability to obtain certain result, and then have greater hope to achieve it. Self-esteem correlates with optimism because of the potential role that optimism has in raising the possibility of successful experiences (Heinonen, Räikkönen, \& Keltikangas-Järvinen, 2005) as the subject who has high self-esteem has a greater sense of worthiness. Therefore, the subjects possibly experience more positive events because they believe to deserve it. Experiencing more situations like this can help to raise the subjective well-being (SWB).

The subjective well-being is the subjective judgment of how much people are happy with their own lives (Diener, Scollon, \& Lucas, 2003). The SWB has an emotional (positive and negative affect), and a cognitive component (life satisfaction). The emotional component reflects the intensity and frequency with which people experience emotions. That is, individuals with high scores for positive affect live intense and frequent episodes of pleasure while subjects with high scores on negative affect have the same experience with episodes of displeasure (Watson, 2005). Levels of affection are stable over time (Lyubomirsky, King, \& Diener, 2005) and there is evidence that positive and negative affects are independent factors (Diener \& Emmons, 1985). Thus, it is possible for a subject to obtain high scores in both dimensions. Results point to a positive correlation of hope with positive affect, and an inverse relationship with negative affect (Brouwer, Meijer, Weekers, \& Baneke, 2008). Norem and Chang (2002) observed a positive correlation between optimism, self-esteem and positive affect.

The cognitive component of SWB, life satisfaction, is the perception that the subjects have about satisfaction with their own lives (Diener, Lucas, \& Oishi, 2005). Life satisfaction was higher in adults who had high scores for hope (Bailey \& Snyder, 2007). Perhaps satisfaction is related to achieving goals and hopeful people reach them more easily due to the high number of routes developed. Magaletta and Oliver (1999) reported the association of hope and optimism with SWB. Furthermore, Wong and Lim (2009) reported in their study results indicating that hope and optimism predict approximately $17 \%$ of the variance in life satisfaction. Wong (2010) states 
that the SWB is a function of the balance of mental states. The balance of mental states and automatic positive thoughts was associated with SWB.

Some authors investigated whether the positive variables are associated with personality traits. Day, Hanson, Maltby, Proctor and Wood (2010) conducted a study linking hope to personality. The authors found a positive correlation between hope and extraversion and a negative correlation between hope and neuroticism. This correlation possibly happened because when searching for a goal, the hopeful subject needs to behave in a certain way that resembles some extrovert behavior. Active, energetic, enthusiastic and assertive are adjectives that describe an extroverted (McCrae \& John, 1992) and hopeful person. The other facets showed no correlation statistically significant.

The correlations between personality and optimism were similar to those obtained with hope. Norem and Chang (2002) found positive correlations between optimism and extraversion. Marshall, Worthman, Kusulas, Hervig and Vickers (1992) found positive correlations among optimism, extraversion and positive affects. Robins, Tracy, Trzesniewski, Potter and Gosling (2001) reported that personality in the FFM explained about 34\% of the self-esteem variance. Individuals with high self-esteem scores were emotionally stable, extraverted, and conscientious, and were somewhat agreeable and open to experience. Personality (especially Extraversion and Neuroticism) was identified by Gutierrez, Gimenez, and Hernandez Puentes (2005) as one of the most important predictors of subjective well-being.

An instrument called Bateria Fatorial de Personalidade (Nunes, Hutz, \& Nunes, 2008) was developed in Brazil for personality assessment. This instrument evaluates the construct according to the Big Five Model. Personality evaluated with this instrument has not yet been correlated with hope, optimism, self-esteem, life satisfaction, and affects. In Brazil there are no published studies correlating hope, optimism, self-esteem, positive and negative affects, life satisfaction, and personality.

\section{Method}

\subsection{Participants}

Two groups of students participated in this study: Americans and Brazilians. The American sample consisted of 179 university students aged from 18 to 61 years (mean age of 25.4; SD =6.9), approximately 62.6\% were women. The Brazilian sample consisted of 499 college students aged from 17 to 53 years, (mean age of 22.1: $\mathrm{SD}=4.7$ ), approximately $60 \%$ were women.

\subsection{Instruments}

The American sample responded to the Adult Dispositional Hope Scale (Snyder et al. 1991), LOT-R (Scheier, Carver, \& Bridges, 1994), Self-Esteem Scale (Rosenberg, 1965), The Satisfaction With Life Scale (Diener, Emmons, Sem, \& Griffin, 1985), and Neo-Pi-R (Costa \& McCrae, 1992) and PANAS (Watson, Clark, \& Tellegan, 1988). The Brazilian sample responded to the Dispositional Hope Scale (Snyder et al., 1991; Pacico, Zanon, Bastianello, \& Hutz, 2013), Life Orientation Revised Test-LOT-R (Scheier, Carver, \& Bridges, 1994; Bastianello, Zanon, Pacico, Reppold, \& Hutz, 2012), Rosenberg Self-Esteem Scale (Rosenberg, 1965; Hutz \& Zanon, 2011), Life Satisfaction Scale (Diener, Emmons, Sem, \& Griffin, 1985; Zanon, Bardagi, Layous, \& Hutz, 2013), Positive and Negative Affect Scale (Watson, Clark, \& Tellegen, 1988; Giacomoni \& Hutz 1997). All these instruments were adapted for use in Brazil. The participants also responded to the FBP (Nunes, Hutz, \& Nunes, 2008), which is an instrument functionally equivalent to NEO-PI-R.

The Adult Dispositional Hope Scale-ADHS was created by Snyder and his colleagues in 1991 to assess dispositional hope. The instrument consists of 12 items. Eight of these items evaluate pathways and agency. The remaining items are filters and are not included for the evaluation of the subject's score. The ADHS was adapted and validated for Brazil and obtained coefficient alpha .80 (Pacico, Zanon, Bastianello, \& Hutz, 2012). A fivepoint Likert scale (1-totally false, 5-completely true) is used to express the degree of agreement with each of 12 items.

Rosenberg Self-esteem Scale (Rosenberg; 1965) measured self-esteem through 10 items. The answers are listed through a four-point Likert scale (1-strongly agree, 2-agree, 3-disagree, and 4-strongly disagree). This instrument was adapted and validated for Brazil (Hutz \& Zanon, 2011) and obtained alpha coefficient of .90.

In order to measure the optimism Scheier, Carver and Bridges (1985) created The Life Orientation Revised 
Test-LOT-R. The instrument has 10 items, three of them evaluate optimism and three evaluate pessimism. The other four items are filters and are not computed for evaluate the scores of the subject. For each item there is a five-point Likert scale (1-strongly disagree, 5-strongly agree) used by the subject to express his agreement. This instrument was adapted and validated for Brazil and obtained coefficient alpha .80 (Bastianello \& Pacico, 2014).

The Life Satisfaction Scale (Diener, Emmons, Larsen, \& Griffin, 1985) consists of five items. The subject uses a seven-point Likert scale to express their agreement with each statement (1-strongly disagree, 7-strongly agree). The scale evaluates the global cognitive aspect of subjective well-being. This instrument was adapted for Brazil (Zanon, Bardaggi, Layous, \& Hutz, 2013) and obtained good psychometric properties (alpha = .87).

The emotional aspect of SWB was assessed on the American sample through the Positive and Negative Affect Schedule (Watson, Clark, \& Tellegan, 1988). The instrument consists of 10 items that assess positive affect and 10 others that assess negative affect. Each item receives a response from 1 (very slightly) to 5 (extremely). The authors reported alpha coefficient of .88 for positive affect and .87 for negative affect. The Brazilian sample answered the Scale of Positive and Negative Affects (Giacomoni \& Hutz, 1997) which was adapted from the original scale (Watson, Clark, \& Tellegan, 1988). The subjects use a five-point Likert scale $(1=$ not at all, $5=$ extremely) to respond to 32 items equally divided into positive and negative affects. The instrument obtained alpha coefficient of .84 for positive affect and .88 for negative affect.

Personality was also evaluated in the two samples. The NEO Pi-R (Costa \& McCrae, 1992) was used to assess personality in the American sample. It was built on the model of the Big Five factors. Each of the five dimensions comprises of six facets. The subject answers the 240 items on a five-point Likert scale (1-strongly disagree to 5-strongly agree). The instrument alpha coefficient between reach .87 to .92 for each of the five dimensions. The Factorial Battery of Personality is an instrument developed in Brazil, which assesses personality according to the FFM. It is functionally equivalent to the NEO-PI. The subject responds to 126 items through a seven-point Likert scale (1-absolutely do not identify with the sentence, 7-describes me perfectly) that describes how the subjects identifies themselves with each proposition. The instrument alpha coefficient reach .74 to .89 for each of the five dimensions.

\subsection{Procedure}

The instruments were administered by two researchers. All students were invited to participate in the research receiving information on how to answer the instruments and on the anonymity and confidentiality of the data. After agreeing to participate, the instruments were distributed. The application was collective, in the classroom, and lasted approximately thirty to forty minutes. The procedures were similar to Brazilians and Americans.

\section{Results}

Pearson correlations were performed to evaluate the relationship between the five facets of personality and hope, optimism, self-esteem, positive and negative affect, and life satisfaction in the Brazilian and American samples. The correlations obtained in the Brazilian sample can be seen in Table 1. Note that the instruments used to assess the Brazilian sample were validated adaptations of American instruments for all variables except for personality. The correlations in the American sample can be seen in Table 2.

To verify the differences between correlations, Fisher's z Tests were performed. The results showed significant differences between the correlations of the two groups in relation to: neuroticism and negative affect $(\mathrm{z}=2.3, p$ $<.03)$, extroversion and life satisfaction $(\mathrm{z}=3.4, p<.02)$, conscientiousness and optimism $(\mathrm{z}=3.89, p<.01)$, conscientiousness and life satisfaction $(\mathrm{z}=2.7, p<.01)$, conscientiousness and positive affect $(\mathrm{z}=3.0, p<.01)$, hope and negative affect $(\mathrm{z}=2.3, p<.03)$, openness and optimism $(\mathrm{z}=2.4, p<.02)$, optimism and hope $(\mathrm{z}=2.5, p$ $<.02)$, optimism and life satisfaction $(\mathrm{z}=2.7, p<.01)$ and self-esteem and negative affect $(\mathrm{z}=2.4, p<.01)$.

The following $t$ tests were performed to compare the means of the Brazilian and the American groups in relation to: hope, optimism, self-esteem, life satisfaction, positive affect and negative affect. The American Likert scale for hope consists of eight points. The adapted Brazilian version is a 5-point scale, the scale. Therefore, the American hope scores were converted to the same scale of Brazil (5 points). These averages are shown in Table 3.

Americans had higher values than Brazilians regarding hope $[\mathrm{t}(420)=4.2, p<.001, \mathrm{~d}=.4$ ( $\mathrm{d}$ is the effect size, Cohen, 1988)], life satisfaction [t(615) $=2.1, p<.05, \mathrm{~d}=.2]$, and positive affect [t(346) $=3.5, p<.001, \mathrm{~d}=.4]$. On the other hand, Brazilians showed higher optimism [t(618) $=2.0, p<.05, \mathrm{~d}=.2]$ and negative affect $[\mathrm{t}(346)$ $=5.9, p<.001, \mathrm{~d}=.6]$. There were no mean differences for self-esteem. 
Table 1. Correlations of personality traits (FBP) and positive psychology variables (Brazilian data).

\begin{tabular}{|c|c|c|c|c|c|c|c|c|c|c|}
\hline Variables & (1) & (2) & (3) & (4) & (5) & (6) & (7) & (8) & (9) & $(10)$ \\
\hline 1) Neuroticism & - & & & & & & & & & \\
\hline 2) Extraversion $N=$ & $\begin{array}{c}-.24 \\
(443)\end{array}$ & - & & & & & & & & \\
\hline 3) Conscientiousness $\mathrm{N}=$ & $\begin{array}{l}-.21 \\
(443)\end{array}$ & $\begin{array}{c}.02 \\
(443)\end{array}$ & - & & & & & & & \\
\hline 4) Agreeableness $N=$ & $\begin{array}{c}-.32 \\
(443)\end{array}$ & $\begin{array}{c}.05 \\
(443)\end{array}$ & $\begin{array}{c}.24 \\
(443)\end{array}$ & - & & & & & & \\
\hline 5) Openness $N=$ & $\begin{array}{c}-.01 \\
(443)\end{array}$ & $\begin{array}{c}.34 \\
(443)\end{array}$ & $\begin{array}{c}.01 \\
(443)\end{array}$ & $\begin{array}{c}-.02 \\
(443)\end{array}$ & - & & & & & \\
\hline 6) Hope N = & $\begin{array}{c}-.44 \\
(362)\end{array}$ & $\begin{array}{c}.31 \\
(362)\end{array}$ & $\begin{array}{c}.35 \\
(362)\end{array}$ & $\begin{array}{c}.27 \\
(362)\end{array}$ & $\begin{array}{c}.07 \\
(362)\end{array}$ & - & & & & \\
\hline 7) Optimism N = & $\begin{array}{c}-.44 \\
(439)\end{array}$ & $\begin{array}{c}.28 \\
(439)\end{array}$ & $\begin{array}{c}.10 \\
(439)\end{array}$ & $\begin{array}{c}.33 \\
(439)\end{array}$ & $\begin{array}{c}.01 \\
(439)\end{array}$ & $\begin{array}{c}.47 \\
(361)\end{array}$ & - & & & \\
\hline 8) Self-esteem $N=$ & $\begin{array}{c}-.64 \\
(169)\end{array}$ & $\begin{array}{c}.37 \\
\text { (169) }\end{array}$ & $\begin{array}{c}.19 \\
(169)\end{array}$ & $\begin{array}{c}.27 \\
\text { (169) }\end{array}$ & $\begin{array}{c}-.03 \\
(169)\end{array}$ & $\begin{array}{c}.62 \\
(169)\end{array}$ & $\begin{array}{c}.69 \\
(171)\end{array}$ & - & & \\
\hline 9) Life satisfaction $N=$ & $\begin{array}{c}-.32 \\
(437)\end{array}$ & $\begin{array}{c}.14 \\
(437)\end{array}$ & $\begin{array}{c}.13 \\
(437)\end{array}$ & $\begin{array}{c}.19 \\
(437)\end{array}$ & $\begin{array}{c}-.08 \\
(437)\end{array}$ & $\begin{array}{c}.41 \\
(358)\end{array}$ & $\begin{array}{c}.40 \\
(435)\end{array}$ & $\begin{array}{c}.43 \\
\text { (167) }\end{array}$ & - & \\
\hline 10) Positive affect $N=$ & $\begin{array}{c}-.25 \\
(168)\end{array}$ & $\begin{array}{c}.42 \\
(168)\end{array}$ & $\begin{array}{c}.06 \\
(168)\end{array}$ & $\begin{array}{c}.02 \\
(168)\end{array}$ & $\begin{array}{c}.05 \\
(168)\end{array}$ & $\begin{array}{c}.39 \\
(168)\end{array}$ & $\begin{array}{c}.33 \\
(167)\end{array}$ & $\begin{array}{c}.41 \\
(167)\end{array}$ & $\begin{array}{c}.42 \\
(166)\end{array}$ & - \\
\hline 11) Negative affect $N=$ & $\begin{array}{c}.58 \\
\text { (171) }\end{array}$ & $\begin{array}{c}-.18 \\
(171)\end{array}$ & $\begin{array}{c}-.06 \\
(171)\end{array}$ & $\begin{array}{c}-.32 \\
(171)\end{array}$ & $\begin{array}{c}.06 \\
(171)\end{array}$ & $\begin{array}{l}-.34 \\
(170)\end{array}$ & $\begin{array}{c}-.53 \\
(169)\end{array}$ & $\begin{array}{l}-.57 \\
(169)\end{array}$ & $\begin{array}{c}-.43 \\
(168)\end{array}$ & $\begin{array}{c}-.20 \\
(168)\end{array}$ \\
\hline
\end{tabular}

Table 2. Correlations of personality traits (NEO PI-R) and positive psychology variables ( $\mathrm{N}=179)$ (USA data).

\begin{tabular}{|c|c|c|c|c|c|c|c|c|c|c|}
\hline Variables & (1) & (2) & (3) & (4) & (5) & (6) & (7) & (8) & (9) & (10) \\
\hline 1) Neuroticism & - & & & & & & & & & \\
\hline 2) Extraversion & -.33 & - & & & & & & & & \\
\hline 3) Conscientiousness & -.19 & .52 & - & & & & & & & \\
\hline 4) Agreeableness & -.31 & .20 & .37 & - & & & & & & \\
\hline 5) Openness & -.01 & .44 & .22 & .22 & - & & & & & \\
\hline 6) Hope & -.42 & .41 & .43 & .29 & .17 & - & & & & \\
\hline 7) Optimism & -.38 & .43 & .42 & .31 & .22 & .54 & - & & & \\
\hline 8) Self-esteem & -.52 & .33 & .31 & .23 & .06 & .56 & .52 & - & & \\
\hline 9) Life satisfaction & -.42 & .35 & .36 & .24 & -.06 & .54 & .58 & .53 & - & \\
\hline 10) Positive affect & -.21 & .39 & .37 & .15 & .20 & .43 & .26 & .38 & .41 & - \\
\hline 11) Negative affect & .39 & -.07 & -.15 & -.22 & .21 & -.11 & -.35 & -.37 & -.35 & -.12 \\
\hline
\end{tabular}

\section{Discussion}

The aim of this paper was to compare data obtained with American and Brazilian samples regarding hope, optimism, self-esteem, personality, and SWB. The subjects of the American sample presented mean scores of hope, life satisfaction, and positive affect higher than those of the Brazilian. This difference can be explained by cultural components or different ways of perceiving life and the world.

Allik and Realo (2004) stated that Americans have an individualistic social configuration. This concept expects that individualists look out more for themselves and their immediate family (nuclear). Unlike the collectivists, who prioritize the goals of the community to which they are strongly connected from an early age, the 
Table 3. American and Brazilian descriptive statistics of the variables in the study.

\begin{tabular}{lcccccc}
\hline \multicolumn{1}{c}{ Variables } & \multicolumn{3}{c}{ USA Data } & \multicolumn{3}{c}{ Brazilian Data } \\
\cline { 2 - 7 } & Mean & Sd & Coefficient Alpha & Mean & Sd & Coefficient Alpha \\
1) Neuroticism & 88.4 & 2.8 & .81 & 3.4 & .8 & .88 \\
2) Extraversion & 12.4 & 18.8 & .87 & 4.2 & .9 & .89 \\
3) Conscientiousness & 119.1 & 15.3 & .89 & 4.8 & .7 & .80 \\
4) Agreeableness & 113.3 & 17.6 & .86 & 5.1 & .8 & .87 \\
5) Openness & 117.1 & 18.9 & .89 & 4.6 & .7 & .78 \\
6) Hope & 33.7 & 3.5 & .76 & .71 .8 & 4.3 & .77 \\
7) Optimism & 22.6 & 4.2 & .74 & 23.4 & 4.6 & .79 \\
8) Self-esteem & 32.2 & 4.9 & .87 & 32.6 & 5.1 & .86 \\
9) Life satisfaction & 25.3 & 5.6 & .78 & 24.2 & 5.8 & .78 \\
10) Positive affect & 35.2 & 5.8 & .80 & 32.9 & 5.0 & .78 \\
11) Negative affect & 19.4 & 6.4 & .83 & 23.6 & 6.8 & .80 \\
\hline
\end{tabular}

individualists search for their own goals. This possibly makes them feel more strongly as agents over the world, because the goals are individual. This perception, coupled with the competition, which is a consequence of individualism, may explain the higher scores of hope in Americans. Hope would serve as a tool for achieving desired and individually traced goals, since the conscientiousness of their targets depends basically on themselves.

Snyder and Lopez (2009) cited a famous sentence by Thomas Jefferson "it's amazing what we can do when we spend our entire time doing something.” The sentence reflects the Americans position towards the world, acting on it, actively causing changes. This positive attitude towards the world can have an impact on the scores of hope, because hopeful subjects create ways to achieve their goals. The conscientiousness of the desired results possibly raises the scores of life satisfaction and positive affect, which had a higher mean than the Brazilian sample. Allik and Realo (2004) stated that individualistic contexts are associated with higher levels of life satisfaction, self-esteem and quality of life. Another possible explanation for the higher means for positive affect is that Americans, compared to the Brazilian sample, may experience more positive situations in their daily lives, such as greater political security, higher quality of public services, etc., which can also contribute to the increase in life satisfaction.

Optimism may have appeared higher in Brazilian because this group is closer to the collectivist pole. Allik and Realo (2004) stated that individualism and collectivism appear as opposite poles of a continuum. In collectivism there is a greater emphasis on common purpose, therefore people work with that in mind. Optimism may appear higher because achieving the goal does not depend on an individual subject, but one in the collective work. Thus, to undertake an action seeking something the subject needs to believe that the result will be positive, even if it does not depend only on its own actions.

The increasing political progress, economic and social aspects of Brazil could justify the high positive expectation of the people regarding their future. The booming economy has given the country greater access to the labor market, increasing the income of the population, their purchasing power and payment of debts. This new socioeconomic scenario has been reported by several studies. Soares (2006), when investigating the welfare of the population since the fall in inequality, found a change in the distribution of income that led gains to $70 \%$ of the population. Experiencing a new paradigm social, economic and political, of course, must be strengthened in the Brazilian belief that more good than bad things will happen in the future.

On the other hand, insecurity in the country and the precariousness of public services are still prevailing, which could explain the high scores of negative affect among Brazilians. Despite the economic development in recent years, citizens are still victims of crime. Besides living with high indices of assaults, robberies and kidnappings, people are exposed to a health-care system that does not guarantee fast and efficient services. These, among other conditions, can cause insecurity, tension and stress that are potentially responsible for high negative 
affect scores.

The differences in the correlations between personality and self-esteem, life satisfaction, optimism and affects (positive and negative) between two samples can be explained by the role that personality exerts on these constructs. The American personality explains a larger part of the variance of self-esteem, life satisfaction, optimism, and positive affect when compared to Brazilians. Nunes, Hutz and Nunes (2008) found self-esteem and neuroticism correlation of $\mathrm{r}=-.60$. Similar results were found in this study.

The greatest impact of personality on the explained variance in life satisfaction, optimism, and positive affect can be explained by the appreciation of the individual among Americans. It is possible that in a culture in which the individual is highly valued across the community (Allik \& Realo, 2004) personality has a greater influence on other characteristics of the subject. In Brazil, a country where social relations are crucial for the individual, perhaps much more than for Americans, personality does not have as much impact on other characteristics of the subject. Still, there is a large amount of variance that is not explained by dispositional factors, both for Americans and for Brazilians, and that may be explained by cultural differences.

Some constructs, such as negative affect on Brazilians, receive greater contribution of personality (neuroticism) in its explained variance. It happens, that associated with neuroticism, there are less favorable conditions of existence (insecurity, poor public services, and other risk factors). This situation causes negative affects to be experienced more intensely in individuals with higher neuroticism scores.

The correlation between negative affect and hope was highest in the Brazilian sample when compared to the American sample. This result occurred because in the American sample the average of the scores obtained on the scale of hope is very high. Thus, the variance that could be explained by the correlation with other aspects decreases, therefore the correlation of hope with negative affect in the American sample is significantly lower than for Brazilians. The same situation could occur between negative affect and self-esteem. Negative affect and self-esteem are more strongly correlated in the Brazilian sample. The very high average of a construct means that little remains to be explained by the correlation with other constructs.

Transcultural studies help to understand how the different constructs appear in subjects of different nationalities. Through them, we can conclude on the generality of a phenomenon, such as the association between two or more variables, or on its particularity, as with hope and negative affect on Americans. The results help to ponder on the effectiveness or not of importing interventions from other countries. When using an intervention that was developed in a country where the phenomenon occurs in a different manner to that in which it will be applied, one can criticize their applicability (Allik, Massoudi, Realo, \& Rossier, 2012). To understand these differences it is necessary to perform transcultural studies.

It is important for the comparison of the results to use the same or equivalent instruments and to use similar procedures in order not to interfere (or interfere uniformly) on collected data. This study was careful to use only instruments comparable among themselves, which adds greater reliability to the data obtained.

\section{References}

Allik, J., Massoudi, K., Realo, A., \& Rossier, J. (2012). Personality and Culture: Cross-Cultural Psychology at the Next Crossroads. Swiss Journal of Psychology, 71, 5-12. http://dx.doi.org/10.1024/1421-0185/a000069

Allik, J., \& Realo, A. (2004). Individualism-Collectivism and Social Capital. Journal of Cross-Cultural Psychology, 35, 29-49. http://dx.doi.org/10.1177/0022022103260381

Aspinwall, L. G., \& Taylor, S. E. (1992). Modeling Cognitive Adaptation: A Longitudinal Investigation of the Impact of Individual Differences and Coping on College Adjustment and Performance. Journal of Personality and Social Psychology, 61, 755-765. http://dx.doi.org/10.1037/0022-3514.63.6.989

Bailey, T. C., \& Snyder, C. R. (2007). Satisfaction with Life and Hope: A Look at Age and Marital Status. The Psychological Record, 57, 233-240.

Bastianello, M. R., Zanon, C., Pacico, J. C., Reppold, C. T., \& Hutz, C. S. (2012). Optimism, Self-Esteem and Personality: Adaptation and Validation of the Brazilian Version of The Revised Life Orientation Test (LOT-R). Manuscript submitted for publication.

Brouwer, D., Meijer, R. R., Weekers, A. M., \& Baneke, J. J. (2008). On the Dimensionality of the Dispositional Hope Scale. Psychological Assessment, 20, 310-315. http://dx.doi.org/10.1037/1040-3590.20.3.310

Cohen, J. (1988). Statistical Power Analysis for the Behavioral Sciences (2nd ed.). Hillsdale, NJ: Lawrence Erlbaum Associates. 
Costa, P. T., \& McCrae, R. R. (1992). Revised NEO Personality Inventory (NEO-PI-R) and NEO Five-Factor Inventory (NEO-FFI) Manual. Odessa, FL: Psychological Assessment Resources.

Day, L., Hanson, K., Maltby, J., Proctor, C., \& Wood, A. (2010). Hope Uniquely Predicts Objective Academic Achievement above Intelligence, Personality, and Previous Academic Achievement. Journal of Research in Personality, 44, 550-553. http://dx.doi.org/10.1016/j.jrp.2010.05.009

Diener , E. Emmons , R. A. Larsen , R. J., \& Griffin , S. (1985). The Satisfaction with Life Scale. Journal of Personality Assessment, 49, 71-75. http://dx.doi.org/10.1207/s15327752jpa4901_13

Diener, E., Lucas, R. E., \& Oishi, S. (2005). Subjective Well-Being: The Science of Happiness and Life Satisfaction. In C. R. Snyder, \& S. J. Lopez (Eds.), Handbook of Positive Psychology (2nd ed., pp. 63-73). New York: Oxford University Press. http://dx.doi.org/10.1093/oxfordhb/9780195187243.013.0017

Diener, E., Scollon, C. N., \& Lucas, R. E. (2003). The Evolving Concept of Subjective Well-Being: The Multifaceted Nature of Happiness. Advances in Cell Aging and Gerontology, 15, 187-219. http://dx.doi.org/10.1007/978-90-481-2354-4_4

Di Paula, A., \& Campbell, J. D. (2002). Self-Esteem and Persistence in the Face of Failure. Journal of Personality and Social Psychology, 83, 711-724. http://dx.doi.org/10.1037/0022-3514.83.3.711

Duckworth, A. L., Steen, T. A., \& Seligman, M. E. P. (2005). Positive Psychology in Clinical Pratice. Annual Review of Clinical Psychology, 1, 629-651. http://dx.doi.org/10.1146/annurev.clinpsy.1.102803.144154

Giacomoni, C. H., \& Hutz, C. S. (1997). A mensuração do bem-estar subjetivo: Escala de afeto positivo e negativo e escala de satisfação de vida [Resumos]. In Sociedade Interamericana de Psicologia (Org.), Proceedings XXVI Congresso Interamericano de Psicologia (p. 313). São Paulo: SIP.

Gutierrez, J. L. G., Jiménez, B. M., Hernández, E. G., \& Puente, C. P. (2005). Personality and Subjective Well-Being: Big Five Correlates and Demographic Variables. Personality and Individual Differences, 38, 1561-1569. http://dx.doi.org/10.1016/j.paid.2004.09.015

Heinonen, K., Raikkonen, K., \& Keltikangas-Jarvinen, L. (2005). Self-Esteem in Early and Late Adolescence Predicts Dispositional Optimism-Pessimism in Adulthood: A 21-Year Longitudinal Study. Personality and Individual Differences, 39, 511-521. http://dx.doi.org/10.1016/j.paid.2005.01.026

Hutz, C. S., \& Zanon, C. (2011). Revisão da adaptação, validação e normatização da Escala de Autoestima de Rosenberg. Avaliação Psicológica, 10, 41-49.

Lyubomirsky, S., King, L., \& Diener, E. (2005). The Benefits of Frequent Positive Affect: Does Happiness Lead to Success? Psychological Bulletin, 131, 803-855. http://dx.doi.org/10.1037/0033-2909.131.6.803

Magaletta, P. R., \& Oliver, J. M. (1999). The Hope Construct, Will, and Ways: Their Relations with Self-Efficacy, Optimism, and General Well-Being. Journal of Clinical Psychology, 55, 539-551.

Marshall, G. N., Wortman, C. B., Kusulas, J. W., Hervig, L. K., \& Vickers, R. R. (1992). Distinguishing Optimism from Pessimism: Relations to Fundamental Dimensions of Mood and Personality. Journal of Personality and Social Psychology, 62, 1067-1074. http://dx.doi.org/10.1037/0022-3514.62.6.1067

McCrae, R. R., \& John, O. P. (1992). An Introduction to the Five-Factor Model and Its Applications. Journal of Personality, 60, 175-215. http://dx.doi.org/10.1111/j.1467-6494.1992.tb00970.x

Norem, J. K., \& Chang, E. C. (2002). The Positive Psychology of Negative Thinking. Journal of Clinical Psychology, 58, 993-1001. http://dx.doi.org/10.1002/jclp.10094

Nunes, C. H. S. S., Hutz, C. S., \& Nunes, M. F. O. (2008). Bateria Fatorial de Personalidade (BFP). Manual Técnico, São Paulo: Casa do Psicólogo.

Pacico, J. C., Zanon, C., Bastianello, M. R., \& Hutz, C. S. (2013). Adaptation and Validation of the Dispositional Hope Scale for Adolescents. Psicologia: Reflexão e Critica, 26, 488-492. http://dx.doi.org/10.1590/S0102-79722013000300008

Peterson, C., \& Seligman, M. E. P. (2004). Character Strengths and Virtues: A Handbook and Classification. New York: Oxford University Press.

Robins, R. W., Tracy, J. L., Trzesniewski, K., Potter, J., \& Gosling, S. D. (2001). Personality Correlates of Self-Esteem. Journal of Research in Personality, 35, 463-482. http://dx.doi.org/10.1006/jrpe.2001.2324

Rosenberg, M. (1965). Society and the Adolescent Self-Image. Princeton, NJ: Princeton University Press.

Scheier, M. F., \& Carver, C. S. (1985). Optimism, Coping, and Health: Assessment and Implications of Generalized Outcome Expectancies. Health Psychology, 4, 219. http://dx.doi.org/10.1037/0278-6133.4.3.219

Scheier, M. F., Carver, C. S., \& Bridges, M. W. (1994). Distinguishing Optimism from Neuroticism (and Trait Anxiety, SelfMastery, and Self-Esteem): A Reevaluation of the Life Orientation Test. Journal of Personality and Social Psychology, 67, 1063-1078. http://dx.doi.org/10.1037/0022-3514.67.6.1063

Snyder, C. R., Harris, C., Anderson, J. R., Holleran, S. A., Irving, L. M., Sigmon, S. T., \& Harney, P. (1991). The Will and the 
Ways: Development and Validation of an Individual-Differences Measure of Hope. Journal of Personality and Social Psychology, 60, 570. http://dx.doi.org/10.1037/0022-3514.60.4.570

Snyder, C. R. (2000). Handbook of Hope: Theory, Measures, and Applications. San Diego, CA: Academic Press. http://dx.doi.org/10.1016/B978-012654050-5/50004-X

Snyder, C. R., \& Lopez, S. J. (2009). Psicologia Positiva: Uma abordagem científica e prática das qualidades humanas (R. C. Costa, Trad.). São Paulo: Artmed.

Soares, S. (2006). Distribuição de renda no Brasil de 1976 a 2004 com ênfase no período entre 2001 e 2004. Brasília: Ipea.

Watson, D., Clark, L. A., \& Tellegan, A. (1988). Development and Validation of Brief Measures of Positive and Negative Affect: The PANAS Scales. Journal of Personality and Social Psychology, 54, 1063-1070. http://dx.doi.org/10.1037/0022-3514.54.6.1063

Watson, D. (2005). Rethinking the Mood and Anxiety Disorders: A Quantitative Hierarquical Model for DSM-V. Journal of Abnormal Psychology, 114, 522-536. http://dx.doi.org/10.1037/0021-843X.114.4.522

Wong, S. S., \& Lim, T. (2009). Hope versus Optimism in Singaporean Adolescents: Contributions to Depression in Life Satisfaction. Personality an Individual Differences, 46, 648-652. http://dx.doi.org/10.1016/j.paid.2009.01.009

Wong, P. T. P. (2010). What Is Existential Positive Psychology? International Journal of Existential Psychology \& Psychotherapy, 3, 1-10.

Zanon, C., Bardagi, M. P., Layous, K., \& Hutz, C. S. (2013). Validation of the Satisfaction with Life Scale to Brazilians: Evidences of Measurement Noninvariance across Brazil and US. Social Indicators Research.

http://dx.doi.org/10.1007/s11205-013-0478-5 